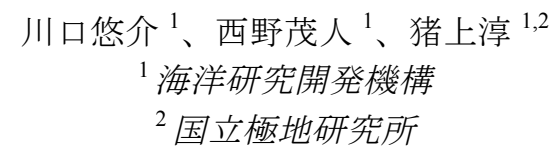

\title{
Fixed-Point Observation of Mixed Layer Evolution in the Seasonally Ice-Free Chukchi Sea: Turbulent Mixing due to Gale Winds and Internal Gravity Waves
}

\author{
Yusuke Kawaguchi ${ }^{1}$, Shigeto Nishino ${ }^{1}$ and Jun Inoue ${ }^{1,2}$ \\ ${ }^{1}$ Japan Agency for Marine-Earth Science and Technology, Japan \\ ${ }^{2}$ National Institute of Polar Research, Japan
}

A fixed-point observation using the R/V Mirai was conducted in the ice-free northern Chukchi Sea of the Arctic Ocean during September of 2013. During the program the authors performed repeated microstructure measurements to reveal the temporal evolution of the surface mixed layer and mixing processes in the upper water column. The shelf region was initially characterized by a distinct two-layer system comprising a warmer/ fresher top layer and a colder/saltier bottom layer. During the two-week observation period, the top-layer water showed two types of mixing processes: near-surface turbulence due to strong wind forcing and sub- surface mixing due to internal gravity waves. In the first week, when the top layer was stratified with fresh sea ice meltwater, turbulent energy related to internal waves propagated through the subsurface stratification, resulting in a mechanical overturning near the pycnocline, followed by enhanced mixing there. In the second week, gale winds directly stirred up the upper water and then established a deeper homogenous layer. The combination of internal wave mixing and wind-driven turbulence may contribute to releasing the oceanic heat into the atmosphere, consequently promoting the preconditioning of surface water freezing.

海洋研究開発機構の「みらい」北極航海（MR13-06）では、海水が後退した北極海チャクチ陸棚域において 2 週間 の固定点観測を実施した。本航海では基礎的な気象・海洋観測に加え、TurboMAP を用いた海洋の微細構造観測や 高精度 GPS センサを搭載した漂流ブイによる流動場の観測を行った。観測の結果、融解期後半のチャクチ陸棚域 において、表層混合層の形成・進化は様々な形で大気場の影響を受けることがわかった。強い海上風は、潜熱・ 顕熱を通して混合層の泠却を促進すると同時に、内部重力波の励起や海面応力による直接的な混合によって混合 層下部を侵食し、層厚を増大させる結果を示した。特に、密度境界面付近で内部波が砕波するイベントでは、躍 層をはさんだ上下層間の熱交換量が増大し、結水前の表層水冷却に大きく貢献する事例が示された。

\section{References}

Kawaguchi, Y., S. Nishino and J. Inoue, Fixed-Point Observation of Mixed Layer Evolution in the Seasonally Ice-Free Chukchi Sea: Turbulent Mixing due to Gale Winds and Internal Gravity Waves, J. Phys. Oceanogr., 45, 836-853, 2015. 